\section{Un hommage à Éric Dewailly, un pionnier de la recherche en épidémiologie environnementale}

C'est avec beaucoup de tristesse que la communauté scientifique canadienne apprenait, le 17 juin dernier, le décès d'Éric Dewailly, professeur à la faculté de Médecine de l'Université Laval et longtemps directeur de l'Unité de recherche en santé publique du Centre de recherche du Centre hospitalier universitaire de Québec. En reconnaissance de l'importance de ses travaux pour l'avancement de la santé publique sur les questions relatives à l'effet sur la santé des contaminants environnementaux, la Revue a ouvert sa page éditoriale à ses plus proches collaborateurs afin de partager cet hommage à un géant de la santé publique canadienne.

\section{Bon voyage Éric}

Le 17 juin dernier décédait de façon tragique notre collègue et ami le docteur Éric Dewailly à l'Île de la Réunion. Sa disparition laisse un vide immense chez les praticiens et chercheurs en santé publique au Canada, en particulier, mais pas exclusivement, dans les domaines de la santé environnementale et de la santé des autochtones.

Éric était adolescent et sur le point de terminer ses études secondaires dans le nord de la France lorsqu'il visita la Côte d'Ivoire. C'est suite à une rencontre avec un médecin œuvrant en prévention des maladies infectieuses dans une clinique locale qu'il prit conscience de mesures susceptibles d'avoir un impact significatif sur la santé des collectivités, telles que la vaccination, le traitement des eaux usées et l'approvisionnement en eau potable. Ce constat fut déterminant dans son choix de carrière. C'est à ce moment qu'il décida d'intégrer la Faculté de médecine de l'Université de Lille puis de faire carrière en santé publique, un choix peu fréquent et peu glorieux dans la France des années 1970.

Éric envisageait d'abord une spécialisation en médecine tropicale mais un programme d'échange France-Québec allait changer sa destinée. De 1983 à 1985, il compléta une formation de deux ans dans le programme de résidence en santé communautaire de la Faculté de médecine de l'Université Laval. Éric et sa conjointe également médecin tombèrent en amour avec le Québec et choisirent de s'y établir. Éric accepta un poste de médecin conseil en santé environnementale au Département de santé communautaire du Centre Hospitalier de l'Université Laval et se joignit au corps professoral du Département de médecine sociale et préventive de la Faculté de médecine de cette même université. Éric s'intéressait alors particulièrement à la toxicologie et compléta d'ailleurs des études doctorales en ce domaine quelques années plus tard. Alors que la santé environnementale en était encore à ses débuts, on lui proposa de mettre sur pied l'un des premiers programmes d'enseignement et de recherche dans ce domaine. Il fut incontestablement un pionnier en santé environnementale au Canada.

C'est au tout début de sa carrière, lors d'un projet portant sur la contamination du lait maternel par les polluants organiques persistants (POPs) au Québec, qu'Éric fit une découverte qui fut déterminante pour sa carrière en recherche. Des échantillons de lait recueillis chez des femmes Inuit du Nunavik, présumés

\section{A Tribute to Éric Dewailly, a Pioneer in Environmental Epidemiology Research}

It was with great sadness that the Canadian scientific community learned, on June 17, 2014, of the death of Éric Dewailly. Éric was a Professor at Laval University's Faculty of Medicine and the long-time Director of the Public Health Research Unit at the Centre Hospitalier Universitaire de Québec. In recognition of the importance of his work in the advancement of public health, on matters relating to the effect on health of environmental contaminants, the Journal opened its editorial page to his closest collaborators in order to share this tribute to a giant in Canadian public health.

\section{Farewell Éric}

On June 17, our colleague and friend Dr. Éric Dewailly died tragically on Réunion Island. His loss leaves an enormous void within Canada's community of public health practitioners and researchers; in particular, but not exclusively, within the fields of environmental health and Aboriginal health.

Éric was a youth on the verge of completing his high school equivalency in the north of France when he visited the Ivory Coast. It was following a meeting with a doctor who was working in infectious disease prevention in a local clinic that he became aware of measures likely to have a significant impact on community health... measures such as vaccination, wastewater treatment and the supply of safe drinking water. This observation was instrumental in his choice of career. It was then that he decided to enter the Faculty of Medicine at the Université de Lille and to build a career in public health, an uncommon and lessthan-glorious choice in 1970s France.

Éric initially considered a specialization in tropical medicine, but a France-Québec exchange program was to change his destiny. From 1983 to 1985, he completed a two-year residency in community health at Laval University's Faculty of Medicine. Éric and his spouse, also a doctor, fell in love with Québec and chose to live there. Éric accepted a position as a medical consultant in environmental health in the Community Health Department at the Centre Hospitalier de l'Université Laval and joined the university's Department of Social and Preventive Medicine. Éric became especially interested in toxicology and completed his doctoral studies in that field a few years later. Although environmental health was still in its infancy, it was suggested to him that he should set up one of the first teaching and research programs in that field. He was unquestionably a pioneer in environmental health in Canada.

It was right at the start of his career, during a project on the contamination of breast milk by persistent organic pollutants (POPs), in Québec, that Éric made a discovery that would be decisive for his research career. Samples of milk gathered from Inuit women in Nunavik - presumed free from contamination due to the distance separating this region from industrial and agricultural zones - contained POP concentrations 10 to 15 times higher than those collected from women in southern Québec. This was the starting point of many projects, carried out by Éric and his team, aimed at studying the effects on health of a variety 
exempts de contamination dû à la distance séparant cette région des zones industrielles et agricoles, contenaient des concentrations 10 à 15 fois plus élevées de POPs que celles mesurées dans le lait récolté auprès de femmes du sud du Québec. Ce fut le point de départ de multiples projets, réalisés par Éric et son équipe, visant à étudier les effets sur la santé de différents contaminants environnementaux tels que les POPs mais aussi le mercure, le plomb et différents pathogènes biologiques auprès de différentes populations autochtones et non-autochtones au Québec, ainsi qu'en Europe, en Polynésie et dans les Antilles.

Par ses interventions uniques dans l'étude des contaminants environnementaux au Québec et dans l'Arctique canadien, Éric fut l'un des plus grands chercheurs mondiaux dans le domaine de l'épidémiologie environnementale. Ses réalisations, ses talents de rassembleur et le caractère fortement interdisciplinaire de ses travaux lui ont valu un fort rayonnement international. Il a joué un rôle-clé au sein de la communauté scientifique préoccupée par la santé des populations des pays circumpolaires.

Éric était indéniablement un visionnaire, un homme d'action et un excellent communicateur. Il avait rapidement compris l'importance de faire cheminer ses résultats de recherche vers les décideurs publics, et ceci bien avant qu'un tel mandat soit inscrit dans les programmes de recherche en santé publique et environnementale au Canada. Ses études portant sur l'évaluation des risques reliés à la contamination de la chaîne alimentaire aquatique ont été remarquées par les leaders de plusieurs communautés tant au Québec, en Arctique canadien que dans les pays circumpolaires. Son profond respect des populations et son implication locale ont favorisé de solides liens et permis aux autorités locales d'identifier les défis prioritaires en matière de santé. À titre d'exemple, les Inuit se sont appropriés ses résultats de recherche pour défendre leur santé et leur bien-être sur les tribunes internationales. L'impact de l'exposition aux POPs sur la santé des enfants Inuit fut l'un des arguments majeurs supportant la mise sur pied de la Convention de Stockholm par le Programme des Nations Unies pour l'Environnement (UNEP) en 2001. Celle-ci fut adoptée par 152 pays, et vise l'élimination de ces substances de la planète. Pour toutes ces raisons, déjà en 2002 et alors que sa carrière ne venait que de débuter, l'ACFAS (l'Association francophone pour le savoir) lui attribuait le prix Michel-Jurdant, en reconnaissance de sa contribution aux sciences de l'environnement.

Éric avait une vaste culture scientifique, plus éclectique que pointue. Il s'intéressait à tout. Avec les années, il a élargi ses champs de recherche à la nutrition et plus récemment, à l'anthropologie. Ses travaux réalisés chez les populations Inuit ont notamment mis en lumière les effets bénéfiques des acides gras polyinsaturés oméga-3 sur la santé cardiovasculaire, lesquels sont présents en quantités exceptionnelles dans plusieurs espèces marines, notamment les mammifères marins. De fil en aiguille, il a développé une expertise sur les aspects de santé publique associés à la mer, un écosystème qu'il affectionnait particulièrement. Au cours des dernières années, il s'est également intéressé à la culture et aux connaissances des populations qui vivent de la mer, soucieux d'intégrer leurs perspectives dans ses recherches et de développer des interventions qui rejoignent l'intérêt de tous pour un objectif commun, la santé. Récemment, il ciblait ses interventions chez of environmental contaminants such as POPs but also mercury, lead and various pathogens among various Aboriginal and non-Aboriginal populations in Québec, as well as in Europe, Polynesia and the Antilles.

Through his singular interventions in the study of environmental contaminants in Québec and in Canada's Arctic, Éric was one of the world's greatest researchers in the field of environmental epidemiology. His accomplishments, his talents as a unifier and the strongly interdisciplinary character of his work earned him a strong international reputation. He played a key role within the scientific community, studying the health of circumpolar countries' populations.

Éric was unquestionably a visionary, a man of action and an excellent communicator. He quickly understood the importance of directing the results of his research to public decision-makers, and this, well before any such mandate was written into Canada's public and environmental health research programs. His studies on risk assessment, relating to the contamination of the aquatic food chain, were noted by a number of community leaders, not only in Québec and Canada's Arctic but also in circumpolar countries. His deep respect for populations, and his local involvement, encouraged solid ties and allowed local authorities to identify the priority challenges in health issues. As an example, the Inuit appropriated his research results to defend their health and welfare on international tribunals.

The impact of the POP exposure on the health of Inuit children was one of the major arguments supporting the implementation of the Stockholm Convention by the United Nations Environment Program (UNEP) in 2001. This was adopted by 152 countries and its aim is to eliminate these substances from the planet. For all of these reasons, in 2002, although his career had just begun, ACFAS (Association francophone pour le savoir) awarded him the Michel Jurdant prize, in recognition of his contribution to environmental science.

Éric had a vast scientific culture, more eclectic than specialized. He was interested in everything. Over the years he expanded his fields of research to include nutrition and, more recently, anthropology. His work with Inuit populations, in particular, shone a light on the beneficial effects on cardiovascular health of omega-3 polyunsaturated fatty acids that are present in exceptional quantities in several marine species, particularly marine mammals. With one thing leading to another, he developed an expertise in public health issues associated with the sea, an ecosystem of which he was particularly fond.

Over the course of the past few years, he was similarly interested in the culture and knowledge of populations who live from the sea, careful to integrate their perspectives into his research and to develop responses that meet the interests of all to achieve a common objective - health. Recently, he steered his interventions to youth, who he presented as being change bringers in healthy-living circles.

Over the course of his career, Éric participated as an expert on numerous scientific committees both in Canada and internationally. He participated in the organization of many scientific conferences and leaves a legacy of a great number of communications and publications. But his many students will remember him, above all, as a fascinating and caring mentor. 
les jeunes, qu'il présentait comme les porteurs de changements pour des milieux de vie en santé.

Au fil de sa carrière, Éric a participé à titre d'expert, à de multiples comités scientifiques, tant au Canada qu'au niveau international. Il a participé à l'organisation de nombreux congrès scientifiques et il laisse en héritage un très grand nombre de communications et de publications. Mais ses nombreux étudiants se souviendront surtout de lui comme d'un mentor bienveillant et attachant.

Au-delà de ses qualités académiques, Éric avait un grand charisme. Bon vivant, il possédait des qualités sociales extraordinaires. C'était un homme d'une grande intelligence, inventif, avec des idées plein la tête et un extraordinaire sens de l'humour. Rêveur, il fascinait. En cela, il a suscité plusieurs vocations. Nombreux sont ceux qui lui doivent une partie de leur carrière.

Le décès d'Éric a suscité nombre de réactions de la part de ses amis, de ses collègues et de ses étudiants. L'ampleur de ces réactions est le reflet de la perte que collectivement, nous avons vécue. En ce qui nous concerne, nous nous souviendrons de lui assis à une table autour d'un bon repas, philosophant avec des amis, développant des idées, quelquefois un peu farfelues...mais toujours orientées vers la solution concrète de problèmes de santé publique. Nous sommes convaincus que c'est le souvenir qu'il aurait aimé laisser.

Salut Éric, bon voyage!

Pierre Ayotte, Benoît Lévesque et Mélanie Lemire

Département de médecine sociale et préventive, Université Laval
Over and above his academic qualities, Éric had great charisma. A bon vivant, he had extraordinary social qualities. This was a man of great intelligence, inventive, with a head full of ideas and an extraordinary sense of humour. A dreamer, he fascinated. As such he sparked many vocations. There are numerous who owe a part of their career to him.

Eric's death elicited many reactions from his friends, his colleagues and his students. The breadth of these reactions is a reflection of the collective loss that we have experienced. For our part, we will remember him sitting at a table enjoying a good meal, philosophizing with friends, developing ideas, sometimes a bit crazy... but always with concrete solutions to public health problems in mind. We firmly believe that this is how he would have wanted to be remembered.

So long, Éric, bon voyage!

Pierre Ayotte, Benoît Lévesque and Mélanie Lemire

Department of Social and Preventive Medicine, Laval University 